\title{
HYPERKALAEMA FOLLOWING SUCCINYLCHOLINE ADMINISTRATION IN NEUROLOGICAL DISORDERS: A REVIEW
}

\author{
R. Briax Swith, M.B., B.s. ${ }^{*}$
}

The Danger of cardiac arrest following administration of succinylcholine has been described in patients with burns, ${ }^{1.2}$ massive trauma, ${ }^{3}$ and tetanus. ${ }^{4}$ More recently, cardiac arrest following the administration of succinylcholine has been reported in patients with spinal cord injury, ${ }^{5.6 . \tau}$ brain injury, ${ }^{8}$ and motor neurone disease."

Paton measured changes in serum potassium levels following the administration of succinylcholine to a series of patients undergoing dental extractions under sodium thiopental anaesthesia. Succinylcholine produced a small, but significant rise in serum potassium. ${ }^{10}$ Similar changes in potassium were seen by Evers, et al. in a series of patients undergoing elective gymaecological surgery. ${ }^{11}$ Stone, Beach, and Hamelberg studied the effects of the administration of succinylcholine in dogs with bilaterally sectioned sciatic nerves or transected spinal cords. ${ }^{12}$ The hyperkalaemia was significant begimning after the 14th day, becoming highly significant at 28 days. Tobey studied the effects of infusion of 0.1 per cent succinylcholine in four paraplegics who had sustained injury 44 to 85 days previously. ${ }^{\top}$ He demonstrated peak levels of serum potassium between 7.3 and $13.6 \mathrm{mEq} / \mathrm{L}$, which returned to normal within 10 to 15 minutes after cessation of the succinylcholine infusion. The interval between the administration of succinylcholine and the taking of the blood sample in the patient in whom a potassium level of $13.6 \mathrm{mEq} / \mathrm{L}$ had been reached, was two minutes. All had EKG evidence of hyperkalaemia. In one patient, cardiac arrest occurred after the administration of $20 \mathrm{mg}$ of succinylcholine, but he was resuscitated successfully. Stone, Beach and Hamelberg reported potassium elevations from 4.3 to $5.6 \mathrm{mEq} / \mathrm{L}$ in one patient following the administration of succinylcholine 23 days after T8-9 transection. ${ }^{5}$ They also reported cardiac arrest following succinylcholine in a quadriplegic patient 46 days after injury. His potassium level rose from 4.5 to $11.2 \mathrm{mEq} / \mathrm{L}$ two minutes after the administration of succinylcholine. The longest interval reported between the onset of paralysis and cardiac arrest following succinylcholine was six months. ${ }^{8}$

High serum potassium has been shown in spinal cord injury patients both by Tobey, ${ }^{\top}$ and by Stone, et al. ${ }^{5}$ This has also been demonstrated in severely burned patients by Tolmie ${ }^{2}$ and in three out of nine severely traumatized patients by Escue. ${ }^{13}$ This is substantial evidence that hyperkalaemia following the administration of succinylcholine is the cause of the cardiac arrest.

The question of protection against cardiac arrest following potassium elevation by the prior administration of d-tubocurarine remains to be settled. It has been

"Department of Anesthesiology, University of Pittsburgh, School of Medicine, Pittsburgh, Pennsylvania 15213 
shown in dogs that previous administration of gallamine may prevent the elevation of serum potassium by succinylcholine. ${ }^{14}$ Birch, studying traumatized patients, demonstrated diminished potassium efflux in seven patients on repeating a dose of succinylcholine after an interval of 30 minutes. ${ }^{15}$ In nine patients, he demonstrated a further diminution in potassium efflux by administering $6 \mathrm{mg}$ of d-tubocurarine, five minutes before the administration of the second dose of succinylcholine.

Weintraub, Heisterkamp, and Cooperman studied serum potassium levels following succinylcholine administration in healthy patients and patients with trauma. ${ }^{16}$ The administration of $0.1 \mathrm{mg}$ per kilo of d-tubocurarine, five minutes before succinylcholine, halved the potassium elevation in patients with trauma.

Cooperman found an increase in serum potassium above $1 \mathrm{mEq} / \mathrm{L}$ in patients with muscle paralysis, secondary to spinal cord trauma, tumor, or $\mathrm{CvA}$, multiple sclerosis, and muscular dystrophy. ${ }^{17}$ These patients had neuromuscular disease for less than one year. Smaller increases in serum potassium were found in patients who had their disease more than one year. Four patients had a second general anaesthesia at a later date for further surgery. These patients were given $6 \mathrm{mg}$ of d-tubocurarine, five minutes before the administration of succinylcholine. A smaller increase in serum potassium was found.

Gronert cites the responses of a burn patient, studied at the U.S. Army Institute of Surgical Research, San Antonio, Texas. ${ }^{18}$ The patient was studied during six operative procedures between the 24th and 45th day post burn. In two of the procedures, $6 \mathrm{mg}$ of d-tubocurarine were administered several minutes prior to a single injection of succinylcholine of $0.7 \mathrm{mg} / \mathrm{kg}$. However, serum potassium still rose to approximately the same levels that were observed when d-tubocurarine was not given ( $4 \mathrm{mEq} /$ liter base line to $6 \mathrm{mEq} /$ liter after succinylcholine). The conclusion was that $6 \mathrm{mg}$ of d-tubocurarine did not block the hyperkalaemic response to a single injection of succinylcholine. In support of this finding, Smith and Grenvik reported cardiac arrest following the administration of succinylcholine in a paraplegic patient who had been given $6 \mathrm{mg}$ d-tubocurarine five minutes earlier. ${ }^{8}$

\section{Conclusion}

Succinylcholine should be administered with caution in patients with burns, massive trauma, and a wide variety of neurological disorders. This latter group has been shown to include patients with paraplegia from brain injury or spinal cord injury, and patients with motor neurone disease. It has not been established that prior administration of d-tubocurarine offers protection against cardiac arrest from potassium elevation after the administration of succinylcholine.

\section{SUMMARY}

A review was made of recent reports of hyperkalaemia, frequently leading to cardiac arrest, following the administration of succinylcholine to patients with nervous system injury or disease. Possible protection by the prior use of d-tubocurarine is discussed. 


\section{Résuní}

On a fait une revue de récents rapports d'hyperkaliémie qui suivent l'administration de succinylcholine et qui conduisent fréquemment à l'arrèt cardiaque chez les malades souffrant de blessures ou de maladies du système nerveux, entre autres blessures de la moëlle épinière, blessures du cerveau et maladies des neurones moteurs. Les malades souffrant de paralysie musculaire secondaire à la sclérose multiple ont présenté aussi une hyperkaliémie dangereuse à la suite d'administration de succinylcholine. On a étudié l'importance du facteur temps dans le développement de la susceptibilité à cette complication. Il est fait mention de la protection possible que constituc l'administration préalable de d-tubocurarine.

\section{REFERENCES}

1. Allan, C. M.; Cullen, W. G.; \& Gllles, D. M. Ventricular fibrillation in a burned boy. Canad. Med. Assoc. J. 85: 432 (1961).

2. Tolmie, J. D.; Joyce, T. H.; \& Mrtcheli, G. D. Succinylcholine danger in the burned patient. Anesthesiology. 28: 467 (1967).

3. Mazze, R. I.; Escue, H. M.; \& Houston, J. B. Hyperkalemia and cardiovascular collapse following administration of succinylcholine in the traumatized patient. Anesthesiology, 31: 540 (1969).

4. Roth, F. \& Wutmrich, H. The clinical importance of hyperkalaemia following suxamethonium administration. Brit. J. Anaesth. 4!:311 (1969).

5. Stone, W. A.; Beach, T. P.; \& Hamelberc, W. Succinylcholine-danger in the spinal-cordinjured patient. Anesthesiology. 32: 168 (1970).

6. Thomas, E. T. Circulatory collapse following succinylcholine: Report of a case. Anes. \& Analg. 48: 333 (1969).

7. Товеу, R. E. Paraplegia, succinylcholine and cardiac arrest. Anesthesiology. $32: 359$ (1970).

8. Smith, R. B. \& Grenvix, A. Cardiac arrest following succinylcholine in patients with central nervous system injuries. Anesthesiology. In Press.

9. ВеACH, T. Cardiac arrest following the administration of succinylcholine in motor neurone disease. Anesthesia and Analgesia (in press).

10. Paton, W. D. M. The effects of muscle relaxants other than muscle relaxation. Anesthesiology. 20: 432 (1959).

11. Evers, W.; Racz, G. B.; \& Dobkin, A. B. A study of plasma potassium and electrocardiographic changes after a single dose of succinylcholine. Canad. Anaesth. Soc. J. 16: 273 (1969).

12. Stone, W. A.: Beach, T. P. \& Hamelberg, W. Succinylcholine-induced hyperkalemia in dogs with transected sciatic nerves or spinal cords. Anesthesiology. 32: 515 (1970).

13. Escue, H. M.; Houston, J. B.; Rudman, H. L.; \& Hansen, H, R. Succinylcholine induced hyperkalemia: A potential hazard following severe trauma or burns. Scientific exhibit. American Society of Anesthesiologists' Meeting, October (1968).

14. Stevenson, D. E. Changes in the blood electrolytes of anesthetized dogs caused by Suxamethonium. Brit. J. Anaesth. 32: 364 (1960).

15. Birch, A. A.; Mitchell, G. D.; Playforn, G. A.; \& Lang, C. A. Changes in serum potassium response to succinylcholine following trauma. JAMA 210: 440 (1969).

16. Weintraub, H. D.; Heisterkamp, D. V.; \& Cooperman, L. H. Brit. J. Anaesth. $41: 1048$ (1969).

17. Cooperman, L. H. Succinylcholine-induced hyperkalemia in neuromuscular disease. JAMA 213: $1867(1970)$.

18. Gronert, G. A. Potassium response to succinylcholine. JAMA 211: 300 (1970). 